\title{
Oxidative Damage in Human Periodontal Ligament Fibroblast (hPLF) after Methylmercury Exposure
}

\author{
Lygia S. Nogueira $\mathbb{D}^{1,2}$ Carolina P. Vasconcelos, ${ }^{2}$ Geovanni Pereira Mitre, ${ }^{3}$ \\ Maria Sueli da Silva Kataoka, ${ }^{3}$ Marcelo O. Lima $\mathbb{D}^{4},{ }^{4}$ Edivaldo H. C. de Oliveira $\mathbb{D}^{, 2,5}$ \\ and Rafael R. Lima $\mathbb{D D}^{1}$ \\ ${ }^{1}$ Universidade Federal do Pará, Laboratório de Biologia Estrutural e Funcional, Belém, Pará, Brazil \\ ${ }^{2}$ Instituto Evandro Chagas, Laboratório de Citogenética e Cultura de Tecidos-SAMAM, Ananindeua, Pará, Brazil \\ ${ }^{3}$ Universidade Federal do Pará, Laboratório de Cultura Celular, Belém, Brazil \\ ${ }^{4}$ Instituto Evandro Chagas, Laboratório de Toxicologia-SAMAM, Ananindeua, Pará, Brazil \\ ${ }^{5}$ Universidade Federal do Pará, Instituto de Ciências Exatas e Naturais, Brazil \\ Correspondence should be addressed to Rafael R. Lima; rafalima@ufpa.br
}

Received 16 July 2019; Revised 17 October 2019; Accepted 24 October 2019; Published 22 November 2019

Academic Editor: Aldrin V. Gomes

Copyright (C) 2019 Lygia S. Nogueira et al. This is an open access article distributed under the Creative Commons Attribution License, which permits unrestricted use, distribution, and reproduction in any medium, provided the original work is properly cited.

\begin{abstract}
Human exposure to mercury $(\mathrm{Hg})$ is primary associated with its organic form, methylmercury $(\mathrm{MeHg})$, through the ingestion of contaminated seafood. However, $\mathrm{Hg}$ contamination is also positively correlated with the number of dental restorations, total surface of amalgam, and organic mercury concentration in the saliva. Among the cells existing in the oral cavity, human periodontal ligament fibroblast (hPLF) cells are important cells responsible for the production of matrix and extracellular collagen, besides sustentation, renewal, repair, and tissue regeneration. In this way, the present study is aimed at investigating the potential oxidative effects caused by $\mathrm{MeHg}$ on hPLF. Firstly, we analyzed the cytotoxic effects of MeHg (general metabolism status, cell viability, and mercury accumulation) followed by the parameters related to oxidative stress (total antioxidant capacity, GSH levels, and DNA damage). Our results demonstrated that $\mathrm{MeHg}$ toxicity increased in accordance with the rise of $\mathrm{MeHg}$ concentration in the exposure solutions (1-7 $\mu \mathrm{M})$ causing $100 \%$ of cell death at $7 \mu \mathrm{M}$ MeHg exposure. The general metabolism status was firstly affected by $2 \mu \mathrm{M} \mathrm{MeHg}$ exposure $(43.8 \pm 1.7 \%)$, while a significant decrease of cell viability has arisen significantly only at $3 \mu \mathrm{M} \mathrm{MeHg}$ exposure $(68.7 \pm 1.4 \%)$. The ratio among these two analyses (named fold change) demonstrated viable hPLF with compromised cellular machinery along with the range of MeHg exposure. Subsequently, two distinct MeHg concentrations $(0.3$ and $3 \mu \mathrm{M})$ were chosen based on LC50 value (4.2 $\mu \mathrm{M})$. hPLF exposed to these two $\mathrm{MeHg}$ concentrations showed an intracellular $\mathrm{Hg}$ accumulation as a linear-type saturation curve indicating that metal accumulated diffusively in the cells, typical for metal organic forms such as methyl. The levels of total GSH decreased $50 \%$ at exposure to $3 \mu \mathrm{M} \mathrm{MeHg}$ when compared to control. Finally, no alteration in the DNA integrity was observed at $0.3 \mu \mathrm{M} \mathrm{MeHg}$ exposure, but $3 \mu \mathrm{M} \mathrm{MeHg}$ caused significant damage. In conclusion, it was observed that MeHg exposure affected the general metabolism status of hPLF with no necessary decrease on the cell death. Additionally, although the oxidative imbalance in the hPLF was confirmed only at $3 \mu \mathrm{M} \mathrm{MeHg}$ through the increase of total GSH level and DNA damage, the lower concentration of $\mathrm{MeHg}$ used $(0.3 \mu \mathrm{M})$ requires attention since the intracellular mercury accumulation may be toxic at chronic exposures.
\end{abstract}

\section{Introduction}

Considered one of the top ten chemicals or groups of chemicals of major public health concern by the World Health
Organization (WHO), mercury is released in thousands of tons into the environment mainly through uncontrolled gold-mining activities. Increased $\mathrm{Hg}$ levels are reported in water, sediments, and fishes $[1,2]$. MeHg is a well-known 
neurotoxin and has been shown to disrupt the function of multiple organs throughout the human body [3].

The main aspect studied on mercury exposure is the oxidative stress scenery. A variety of in vitro and in vivo models have shown that $\mathrm{MeHg}$ binds to total glutathione (GSH). This protein is the substrate for glutathione S-transferase (GST) and plays a key role in cellular detoxification of xenobiotics and in excessive production of oxygen species. The decreased level of total GSH or the ratio between GSH/GSSG results in oxidative stress and evidences an important molecular mechanism in MeHg-induced toxicity $[4,5]$. Related to mercury exposure, oxidative stress is also associated with mitochondrial dysfunction [6] and alterations on membrane permeability and macromolecule structure (DNA, protein, and lipids), due to their high affinity for sulphydryl groups and thiols [7].

Concerning human exposure to mercury, it is primarily associated particularly with the consumption of contaminated fish and other seafood that turns $\mathrm{MeHg}$ the most toxic form of this metal [8]. Additionally, it is important to consider that levels of mercury in the blood also have a positive correlation with the number of dental restorations [9], the total surface of amalgam, and organic mercury concentration in the saliva [10]. It is noteworthy that although mercury is found in metallic form in restorations, there are commensal bacteria or normal microflora found in the mucosal surfaces of oral cavity, which are involved in the methylation of mercury, turning it into the most toxic form of exposure $[11,12]$.

Among the different types of cells in the oral cavity, human periodontal ligament fibroblast (hPLF) cells are the most numerous population and responsible for different functions to maintain the periodontal homeostasis. These cells produce and secrete extracellular matrix components having the most production of collagen $[13,14]$. Besides that, hPLF may also produce mineralized tissue, showing higher alkaline phosphatase activity and being consider an essential cell to play a role in the remodeling of alveolar bone [15]. Cells of the periodontal ligament also participate actively in immune and inflammatory events in periodontal diseases producing cytokine and chemokines [16] and have high active metabolism [17] probably due to their remarkable capacity for renewal and repair of the periodontal ligament; consequently, the effects caused by $\mathrm{MeHg}$ exposure on their metabolism probably implicate directly to their function in the oral cavity. These facts turn this cell type an essential and ideal model for $\mathrm{MeHg}$ research for oral cavity.

Based on this, the present study is aimed at investigating the effects of the exposure to $\mathrm{MeHg}$ in hPLF from toxicological and oxidative stress perspective. Firstly, in vitro experiments were performed to evaluate the effects of a range of $\mathrm{MeHg}$ concentrations (1-7 $\mu \mathrm{M})$ in hPLF general metabolism status and viability. Based on cell viability results, the lethal concentration for $50 \%$ of the population (LC50) was calculated by Probit method and two different $\mathrm{MeHg}$ concentrations $(0.3$ and $3 \mu \mathrm{M}$ ) were chosen to proceed the experiments. Further, exposed hPLFs were assessed by intracellular mercury accumulation parameters of oxidative stress (GSH levels and DNA damage).

\section{Material and Methods}

2.1. Cell Culture. hPLFs were cultured in Dulbecco's modified Eagle's medium (DMEM) and Ham's F-12 nutrient medium $(1: 1)$, supplemented with $10 \%$ foetal bovine serum (FBS), $100 \mathrm{U} / \mathrm{mL}$ penicillin, and $100 \mu \mathrm{g} / \mathrm{mL}$ streptomycin, incubated at $37^{\circ} \mathrm{C}$ in a $5 \% \mathrm{CO}_{2}$. The medium was changed every $48 \mathrm{~h}$. When cells became fully confluent, they were passaged using $0.25 \%$ trypsin solutions and seeded in new flasks. Passages until 15 were used in our experiments. This cell population was confirmed as human periodontal fibroblast cells by indirect immunofluorescence staining target antigens, the vimentin and fibronectin proteins.

2.2. General Metabolism Status. General metabolism status was measured using the MTT protocol [18]. For this, hPLFs were seeded in a 96-well plate at concentration of $1 \times 10^{4}$ cell/well and exposed to a medium containing different concentrations of $\mathrm{MeHg}, 1,2,3,4,5,6$, and $7 \mu \mathrm{M}$, with no FBS supplementation. Control group was maintained in fresh culture medium. After $24 \mathrm{~h}$ exposure, the medium was removed and replaced by new culture medium containing MTT $(500 \mu \mathrm{g} / \mathrm{mL})$ and incubated for 2 hours. In the end, the medium was removed and $100 \mu \mathrm{L}$ of DMSO was added to dissolve the formazan crystals. Absorbance was recorded at $550 \mathrm{~nm}$ using GloMax ${ }^{\circledR}$-Multi Detection System (Promega). Results were expressed in percentage of the control (\%).

2.3. Cell Viability and LC50. hPLFs were seeded in a concentration of $1 \times 10^{4}$ cells/well and cultured in fresh medium for $24 \mathrm{~h}$. After this, the medium was replaced for a new medium containing $\mathrm{MeHg}$ in the same concentrations used for MTT, with no FBS supplementation. After the exposure time, the medium was removed and hPLFs were washed with EDTA solution $(10 \mathrm{mM})$ to remove possible loosely bound mercury of the cell surface. Following that, cells were detached using trypsin and centrifuged $(2300 \mathrm{~g}, 5$ minutes). Pellets containing the hPLF were resuspended in fresh culture medium and counted under a light microscope (200x magnifications). Cell viability (\% of viable cells from the total number of cells) was determined using Trypan Blue (0.04\%) exclusion assay. The results were expressed in percentage (\%) and used to determine the lethal concentration for $50 \%$ of the population (LC50) by Probit analysis. Based on LC50 results, two MeHg concentrations that represent 7 and $70 \%$ of LC50 were chosen to perform the following analyses: 0.3 and $3 \mu \mathrm{M}$, respectively. The lower concentration $(0.3 \mu \mathrm{M}$ or $\sim 60 \mu \mathrm{g} / \mathrm{L})$ represents values observed in humans exposed at Brazilian Amazon region communities while $3 \mu \mathrm{M}$ (or $\sim 600 \mu \mathrm{g} / \mathrm{L}$ ) is considerably toxic.

2.4. Ration between General Metabolism Status and Cell Viability. Cells may vary their metabolism due to exposure to physical or chemical agents, whether or not related to different doses or concentrations of the compounds. However, variations in MTT assay values may not reflect these alterations because it is not directly related to a possible decrease or increase of the number of viable cells after experimentation [19]. Thus, in our study, it will analyze the ratio between 
the general metabolism status (MTT assay) and the cell viability at correspondent treatment. As a result, this analysis will enable us to demonstrate an increase or decrease in cell metabolic status of hPLF related to the different MeHg exposures. The results were expressed as fold change.

2.5. Intracellular $\mathrm{Hg}$ Concentration. hPLFs were detached from 24-well microplates after exposure to 0.3 and $3 \mu \mathrm{M}$ $\mathrm{MeHg}$ and centrifuged $(2300 \mathrm{~g}, 5$ minutes), and the pellets were dried overnight $\left(37^{\circ} \mathrm{C}\right)$. Following that, samples were digested with nitric acid (Merck, St. Louis, MO, USA) and diluted with Milli-Q water. The total $\mathrm{Hg}$ concentration (THg) in the digested samples was analyzed by cold vapour atomic absorption (Automatic Analyzer, HG-20, Sanso Company), as previously described by Akagi et al. [20]. $\mathrm{Hg}$ content in hPLF cells was expressed as $\mu \mathrm{M}$ $\mathrm{THg} / 10^{5}$ cells, considering the amount of $\mathrm{Hg}$ measured in the cell.

2.6. GSH Levels. Levels of total glutathione in the reduced form (GSH) were analyzed using GSH/GSSG-Glo ${ }^{\mathrm{TM}}$ Assay (Promega, Madison, WI, USA) according to the manufacturer's instruction. After $24 \mathrm{~h} \mathrm{MeHg}$ exposure, the medium was removed and cell lysis was performed using total glutathione reagent for 5 minutes. Following that, the lysate was incubated with luciferin generation reagent. After 30 minutes, luciferin detection reagent was added to each well and solution equilibrated for 15 minutes at room temperature. Luminescence was read using GloMax $^{\circledR}$ Multi Detection System (Promega) and data expressed as $\mu \mathrm{M}$ GSH/viable cells.

2.7. Comet Assay. DNA damage was analyzed using the single-cell gel electrophoresis (SCGE) alkaline comet assay, based on the protocol described by Sing and Stephens [21]. hPLFs exposed to 0.3 and $3 \mu \mathrm{M}$ were detached after $24 \mathrm{~h}$ $\mathrm{MeHg}$ exposure, and the formed pellet was resuspended into $300 \mu \mathrm{L}$ of new cell culture medium. An aliquot $(20 \mu \mathrm{L})$ was homogenated with $120 \mu \mathrm{L}$ of low-melting agarose and added to the slides pretreated with agarose layer. After drying, slides were incubated in lyse solution (in $\mathrm{M}: 2.5 \mathrm{NaCl}, 0.1$ EDTA, 0.01 Tris, $1 \%$ Triton X-100) and maintained overnight at $4^{\circ} \mathrm{C}$. Following that, slides were placed into the electrophoresis solution (in mM: $300 \mathrm{NaOH}, 1$ EDTA; $\mathrm{pH}$ 13) for 20 minutes for the unwinding of the DNA. Electrophoresis was performed for 20 minutes at $30 \mathrm{~V}(1 \mathrm{~V} / \mathrm{cm})$ and $300 \mathrm{~mA}$. The last steps were to neutralize the slides using $0.4 \mathrm{M}$ Tris buffer ( $\mathrm{pH} 7.5$ ), stain them with DAPI (Enzo Life Sciences, NY, USA), and analyze them using a fluorescence microscopy (Zeiss Imager Z2, connected to the software Axiovison 4.8, Zeiss, Alemanha). One hundred cells per sample were automatically analyzed through Komet Software ${ }^{\circledR}$. DNA damage was expressed as the length of the comet tail in percentage.

2.8. Data Presentation and Statistical Analyses. Experiments were performed using three different passage numbers $(n=3)$. Therefore, each value represents the mean of these replicates and they are expressed as the mean \pm standard error. Comparisons among treatments were performed using factorial analysis of variance (ANOVA) followed by the Tukey test. ANOVA assumptions (data normality and homogeneity of variances) were previously verified. Data were mathematically transformed when necessary. In all cases, the significance level adopted was 95\% $(\alpha=0.05)$. Statistical analyses were performed using the software SigmaPlot 11.0 (Systat Soft, Germany).

\section{Results}

3.1. MeHg Toxicity. General metabolism status in hPLF exposed to $1 \mu \mathrm{M}$ MeHg was similar to control but dropped significantly at $2 \mu \mathrm{M} \mathrm{MeHg}$ exposure $(43.8 \pm 1.7 \%)$, declining until $6 \mu \mathrm{M} \mathrm{MeHg}(5.9 \pm 1.7 \%)$ and being not observed at $7 \mu \mathrm{M} \mathrm{MeHg}$ treatment (Figure 1(a)).

Cell viability decreased significantly in the hPLF exposed to $3 \mu \mathrm{M}$ treatment $(68.7 \pm 1.4 \%)$. Exposure to $4 \mu \mathrm{M} \mathrm{MeHg}$ had no statistical difference $(54.5 \pm 9.3 \%)$ compared to $3 \mu \mathrm{M} \mathrm{MeHg}$, while 5 and $6 \mu \mathrm{M}$ MeHg decreased significantly to $29.0 \pm 2.9 \%$ and $24.6 \pm 10.8 \%$, respectively. No viable hPLFs were observed after exposure to $7 \mu \mathrm{M} \mathrm{MeHg}$ (Figure 1(b)). Using cell viability results, the lethal concentration of $50 \%$ of population (LC50) was calculated and represented $4.2 \mu \mathrm{M} \mathrm{MeHg}$. Based on that, concentrations of 7 and $70 \%$ of the LC50 were chosen to perform the following analyses: 0.3 and $3 \mu \mathrm{M}$, respectively.

The fold change calculated by the ratio between general metabolism status and cell viability demonstrated a significant decrease at $2 \mu \mathrm{M}$ MeHg exposure and remained similar until $6 \mu \mathrm{M}$ (Figure 1(c)) which implies a nondose response.

Intracellular total $\mathrm{Hg}$ ( $\mathrm{THg}$ ) concentration in hPLF exposed to 0.3 and $3 \mu \mathrm{M} \mathrm{MeHg}$ increased significantly to $0.074 \pm 0.008 \mu \mathrm{M}$ and $0.457 \pm 0.026 \mu \mathrm{M}$, respectively. As expected, intracellular $\mathrm{Hg}$ was not observed in the control cells (Figure 2).

3.2. Oxidative Stress Parameters. The total glutathione (GSH) levels at hPLF had a significant decrease in the higher $\mathrm{MeHg}$ exposure $(0.9 \pm 0.1 \mu \mathrm{M} /$ viable cells $)$ comparing to control $(2.0 \pm 0.12 \mu \mathrm{M} /$ viable cells) and $0.3 \mu \mathrm{M}$ MeHg exposure $(1.2 \pm 0.2 \mu \mathrm{M} /$ viable cells; Figure 3$)$. Decreasing levels of total GSH is considered biomarker of oxidative stress, and it is confirmed in hPLF by a significant increase of DNA damage at $3 \mu \mathrm{M} \mathrm{MeHg}(49.9 \pm 10.6 \%)$ when compared to control and $0.3 \mu \mathrm{M} \mathrm{MeHg}(18.6 \pm 3.8 \%$ and $16.7 \pm 4.6 \%$, respectively; Figure 4).

\section{Discussion}

For the first time in the literature, in vitro experiments using hPLF were performed to evaluate the effects of MeHg exposure. In our study, these effects were primarily associated with oxidative stress parameters through the decreased level of total GSH and occurrence of DNA damage. However, hPLF general metabolism status was affected with no necessary changes on their cell viability. These combined results indicate an impairment of their cellular functions and consequently alterations in the periodontal homeostasis. 


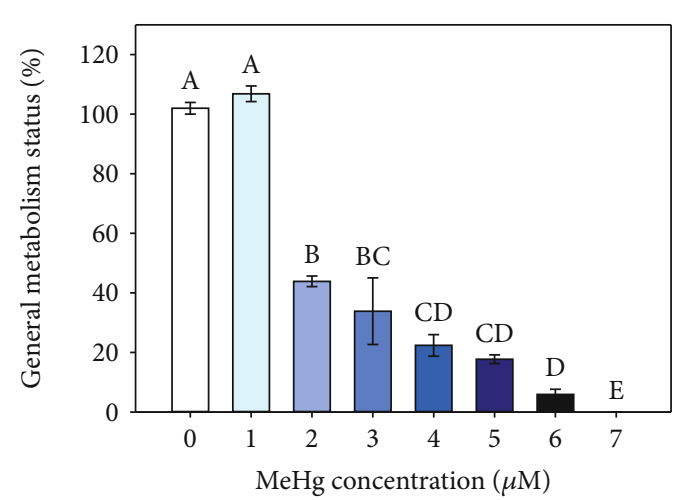

(a)

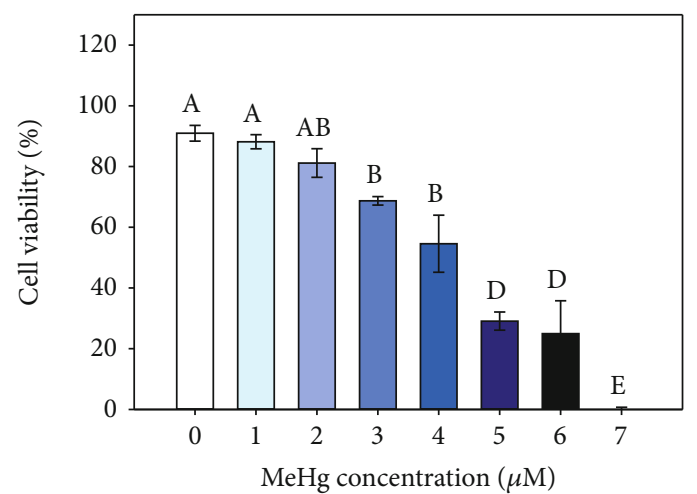

(b)

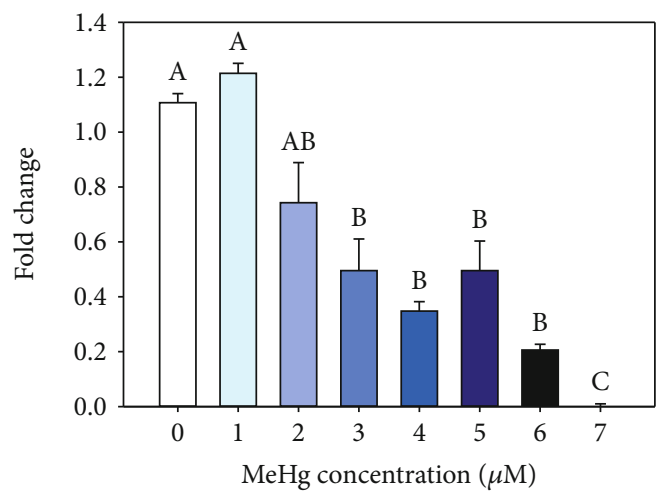

(c)

Figure 1: General metabolism status (a), cell viability (b), and ratio between metabolism status and cell viability (c) in hPLF exposed the range of 1 to $7 \mu \mathrm{M} \mathrm{MeHg}$. It was observed $100 \%$ of dead hPLF cells after $7 \mu \mathrm{M} \mathrm{MeHg}$ exposure. Data are expressed as mean \pm standard error $(n=3)$. Means sharing the same letters are not statistically significant.

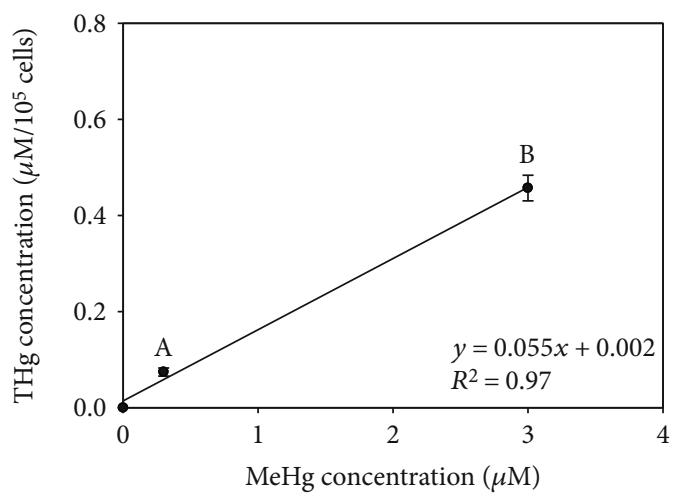

FIGURE 2: Total intracellular mercury concentration (THg) in $\mathrm{hPLF}$ exposed to 0.3 and $3 \mu \mathrm{M}$ MeHg for $24 \mathrm{~h}$. Data are expressed as mean \pm standard error $(n=3)$. Different letters indicate significantly different mean values among treatments.

To initiate the evaluation on MeHg effects on hPLF, we firstly performed experiments using concentrations that ranged from 1 to $7 \mu \mathrm{M}$ and analyzed general metabolism status and cell viability. As expected, $\mathrm{MeHg}$ toxicity increased in parallel to the increase of metal concentration in the exposure solutions, causing $100 \%$ of not viable cells at $7 \mu \mathrm{M}$ MeHg. hPLF sensitivity is also observed after these cells were exposed to $\mathrm{Cu}, \mathrm{Ni}$, and $\mathrm{Zn}$. However, San Miguel and

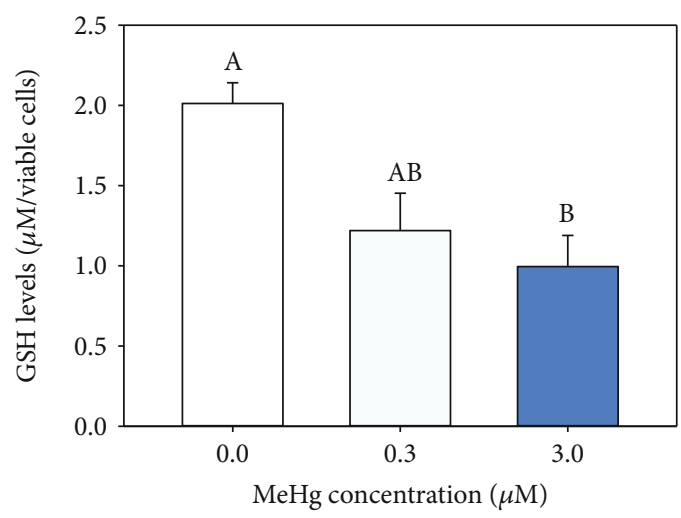

Figure 3: GSH levels in hPLF exposed to 0.3 and $3 \mu \mathrm{M} \mathrm{MeHg}$ for $24 \mathrm{~h}$. Data are expressed as mean \pm standard error $(n=3)$. Means sharing the same letters are not statistically significant.

co-authors [22] used higher concentrations and different times of exposure when compared to our study. Metal concentrations ranged from 30 to $40 \mu \mathrm{M} \mathrm{Cu}$ or $\mathrm{Zn}$ and 1 to $2 \mathrm{mM} \mathrm{Ni}$, and the exposure occurred for 60 minutes.

Interestingly, in the present study, hPLF cell viability decreased at $3 \mu \mathrm{M} \mathrm{MeHg}$ exposure, but the general metabolism status dropped significantly at $2 \mu \mathrm{M} \mathrm{MeHg}$ exposure. It is important to note that the MTT assay used in our study 


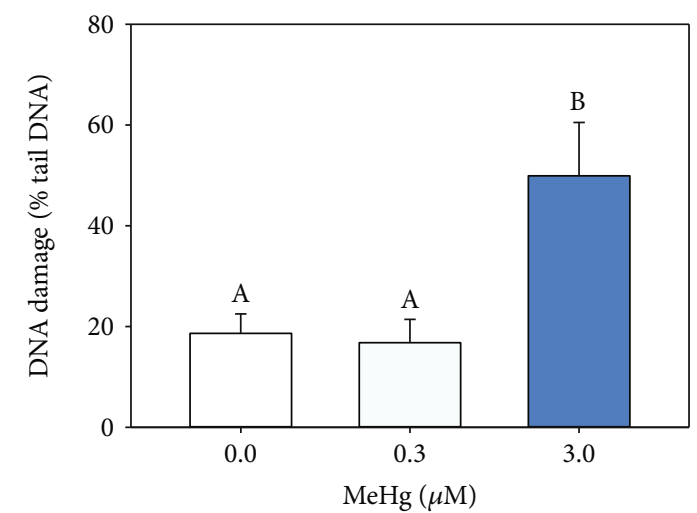

FIgure 4: Percentage of DNA damage in the tail of hPLF kept under control $(0 \mu \mathrm{M} \mathrm{MeHg})$ and exposed to 0.3 and $3 \mu \mathrm{M}$ $\mathrm{MeHg}$ for $24 \mathrm{~h}$. Data are expressed as mean \pm standard error $(n=3)$. Different letters indicate significantly different mean values among treatments.

for general metabolism status evaluation is usually considered an appropriate indicator of mitochondrial function or directly related to the number of living cells $[23,24]$. However, Stockert and co-authors [25] using intracellular fluorescent markers confirmed the biochemical evidences that MTT conversion occurs mainly in the cytoplasm by nicotinamide adenine dinucleotide coenzyme (NADH) and dehydrogenases associated with the endoplasmic reticulum [26, 27], lysosome vesicles [28], and plasma membrane [28]. Thus, the use of MTT assay as a direct measure of mitochondrial activity or living cells would be a highly indirect method [19]. Using this new approach for MTT assay, it was possible to observe through the fold change analysis that compromised hPLF cellular machinery is observed from the $2 \mu \mathrm{M} \mathrm{MeHg}$ treatment and remains with no differences along the range of $\mathrm{MeHg}$ exposure, which implies in a nondose response.

From the measurements of cell viability, we were able to calculate the LC50 of hPLF that represents $4.2 \mu \mathrm{M} \mathrm{MeHg}$ (or $842.5 \mu \mathrm{g} / \mathrm{L}$ ). Unfortunately, it was not possible to compare our LC50 results directly to previously published studies with other cell types, since they were calculated based on MTT assay, in spite of the relevant restrictions already demonstrated concerning the use of this method as an indicator of cell viability [19]. However, it is possible to mention that LC50 calculated in this study is extremely high when compared to mercury concentration found in human blood. In Brazilian Amazon fishing communities, the total mercury concentration in the blood is about $27 \mu \mathrm{g} / \mathrm{L}(0.13 \mu \mathrm{M})$ but some individuals have values above the average, such as $141 \mu \mathrm{g} / \mathrm{L}(6.3 \mu \mathrm{M})$ [29]. As mentioned in Material and Methods, to proceed the experiments evaluating $\mathrm{MeHg}$ effects on hPLF, we opted to use two different concentrations, 0.3 and $3 \mu \mathrm{M}$.

hPLF exposed to 0.3 and $3 \mu \mathrm{M}$ of $\mathrm{MeHg}$ showed a linear increase of intracellular $\mathrm{Hg}$ accumulation. Although the experiments were performed using only two $\mathrm{MeHg}$ concentrations, linear-type kinetics observed in the accumulation reflects a diffusive accumulation of this metal from the extracellular medium. The presence of organic grouping methyl associated with $\mathrm{Hg}$ gives this metal this diffuse ability through biological/cellular membranes due to its lipophilic characteristic [30].

The presence of intracellular mercury is recognized to cause oxidative stress in vivo and in vitro studies [31]. GSH is the primary defense against the excessive generation of harmful ROS [4] by the presence of sulfhydryl group which serves as an antioxidant [32]. In this way, it was performed a specific GSH assay on hPLF exposed to MeHg. The depletion of total GSH in hPLF exposed to $3 \mu \mathrm{M} \mathrm{MeHg}$ is explained by the interaction with intracellular thiols being the main target of MeHg. However, the mechanism of $\mathrm{MeHg}$ toxicity in hPLFs was different from those observed in glioblastoma cells [5]. No changes in the GSH levels were observed in exposed glioblastoma cells exposed to $1 \mu \mathrm{M}$ $\mathrm{MeHg}$ taking place a significant increase of GSSH levels (12-fold). The reduction of total glutathione level (GSH) is a confirmed endpoint of the misbalance between the production of reactive oxygen species and antioxidant defenses, which results in oxidative stress.

In the present study, another evidence of oxidative stress in exposed hPLF was the significant DNA damage at $3 \mu \mathrm{M}$ $\mathrm{MeHg}$. Once accumulated, mercury is able to produce reactive oxygen species that react directly with DNA or induce conformational changes in DNA repair enzymes and protein of microtubules [33]. It is important to note that DNA damage in hPLF depends on $\mathrm{MeHg}$ concentration once cells exposed to $0.3 \mu \mathrm{M} \mathrm{MeHg}$ did not differ from control. Comet assay applied in our study is a usual technique to evaluate the induced effects of metals released from orthodontic appliances on buccal cells $[34,35]$ and gingival fibroblasts [36]. It is possible to detect DNA single- and double-strand breaks, alkali-labile sites (ALS), DNA-DNA/DNA-protein cross-linking, and SSB associated with complete excision repair sites. Single- and double-strand breaks may cause apoptosis through inactivating key genes or leading chromosomal aberrations $[37,38]$. In hPLF exposed to $\mathrm{MeHg}$, the typical nucleus of apoptotic cells was not observed through comet assay analysis in the higher $\mathrm{MeHg}$ concentration. However, Contreras and coauthors [37] expose gingival fibroblast cells to $\mathrm{Ni}$ and observed apoptosis markers, such as DNA fragmentation and caspase-3 activation, which are characteristic of apoptosis. Additionally, $\mathrm{Cu}$ and $\mathrm{Ni}$ reduced significantly the DNA synthesis in gingival fibroblasts and hPLF [39] and DNA damage in oral mucosa cells [40]. Thus, although we did not observe hPLF in apoptotic process via comet assay, we strongly recommend further analyses to evaluate specifically apoptotic pathway in hPLF exposed to $\mathrm{MeHg}$.

Taken together, the use of the fold change analysis revealed the presence of viable hPLF along the range of metal exposures with compromised cellular machinery, arising especially between treatments of 2 and $4 \mu \mathrm{M} \mathrm{MeHg}$. Although these concentrations are not relevant for human mercury accumulation, the reduction on general metabolism status affects hPLF functions once oral cavity diseases may be related to other systemic problems. Furthermore, it is important to note that despite the lower $\mathrm{MeHg}$ concentration $(0.3 \mu \mathrm{M})$ did not exert any negative effect in the analyzed 


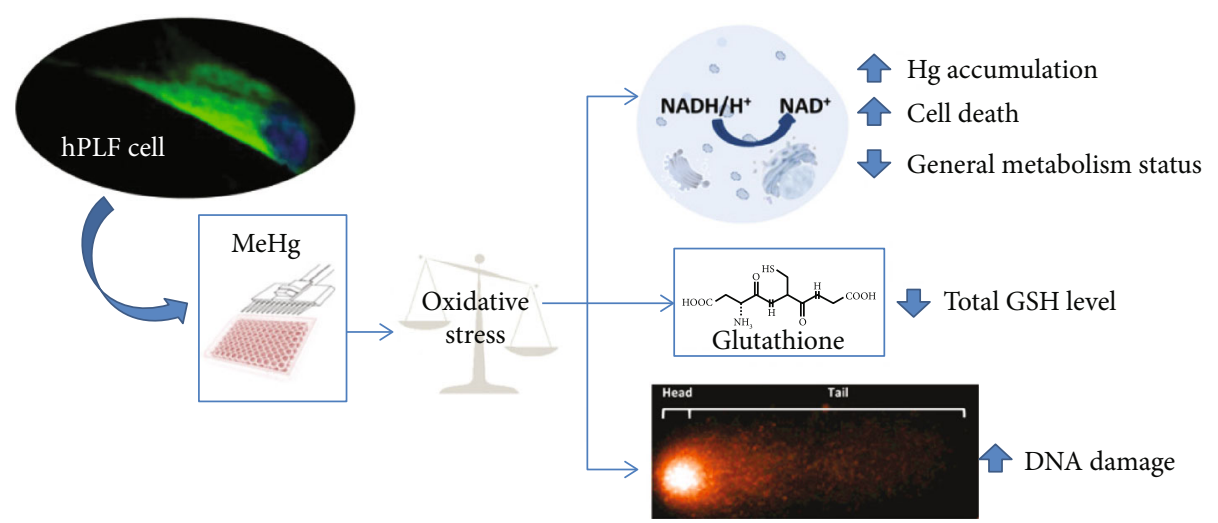

FIGURE 5: Graphical abstract with description of the main results found in this article.

parameters, hPLF accumulated $\mathrm{Hg}$ which may implicate in different consequences if these cells were exposed to chronic manner. The main results found in this research are summarized in Figure 5.

\section{Data Availability}

In our manuscript entitled "Oxidative damage in human periodontal ligament fibroblast (hPLF) after methylmercury exposure", all data used to support the conclusions are presented within the manuscript. Therefore, no data from the repository were used to support this study.

\section{Conflicts of Interest}

The authors declare no conflict of interest.

\section{Acknowledgments}

The authors would like to thank the Evandro Chagas Institute for the support. This study was financed in part by the Coordenação de Aperfeiçoamento de Pessoal de Nível Superior-Brasil (CAPES)-Finance Code 001. Lygia S. Nogueira was supported by Programa Nacional de Pós-Graduação (PNPD/CAPES).

\section{References}

[1] R. G. Cesar, S. Egler, H. Polivanov, Z. Castilhos, and A. P. Rodrigues, "Mercury, copper and zinc contamination in soils and fluvial sediments from an abandoned gold mining area in southern Minas Gerais State, Brazil," Environment and Earth Science, vol. 64, no. 1, pp. 211-222, 2011.

[2] M. Roulet, M. Lucotte, N. Farella et al., "Effects of recent human colonization on the presence of mercury in Amazonian ecosystems," Water, Air, and Soil Pollution, vol. 112, no. 3-4, pp. 297-313, 1999.

[3] Y. S. Hong, Y. M. Kim, and K. E. Lee, "Methylmercury exposure and health effects," Journal of Preventive Medicine \& Public Health, vol. 45, no. 6, pp. 353-363, 2012.

[4] A. A. dos Santos, B. Ferrer, F. M. Gonçalves et al., "Oxidative stress in methylmercury-induced cell toxicity," Toxics, vol. 6, no. 3 , p. 47,2018
[5] S. Robitaille, R. J. Mailloux, and H. M. Chan, "Methylmercury alters glutathione homeostasis by inhibiting glutaredoxin 1 and enhancing glutathione biosynthesis in cultured human astrocytoma cells," Toxicology Letters, vol. 256, pp. 1-10, 2016.

[6] B. O. Lund, D. M. Miller, and J. S. Woods, "Studies on Hg(II)induced $\mathrm{H}_{2} \mathrm{O}_{2}$ formation and oxidative stress in vivo and in vitro in rat kidney mitochondria," Biochemical Pharmacology, vol. 45, no. 10, pp. 2017-2024, 1993.

[7] S. J. Flora, M. Mittal, and A. Mehta, "Heavy metal induced oxidative stress \& its possible reversal by chelation therapy," The Indian Journal of Medical Research, vol. 128, no. 4, pp. 501-523, 2008.

[8] K. Abass, A. Huusko, H. K. Knutsen et al., "Quantitative estimation of mercury intake by toxicokinetic modelling based on total mercury levels in humans," Environment International, vol. 114, pp. 1-11, 2018.

[9] L. Yin, K. Yu, S. Lin, X. Song, and X. Yu, “Associations of blood mercury, inorganic mercury, methyl mercury and bisphenol A with dental surface restorations in the U.S. population, NHANES 2003-2004 and 2010-2012," Ecotoxicology and Environmental Safety, vol. 134, pp. 213-225, 2016.

[10] J. Leistevuo, T. Leistevuo, H. Helenius et al., "Dental amalgam fillings and the amount of organic mercury in human saliva," Caries Research, vol. 35, no. 3, pp. 163-166, 2001.

[11] B. Henderson and M. Wilson, "Commensal communism and the oral cavity," Journal of Dental Research, vol. 77, no. 9, pp. 1674-1683, 1998.

[12] R. Q. Yu, J. R. Reinfelder, M. E. Hines, and T. Barkay, "Mercury methylation by the methanogen Methanospirillum hungatei," Applied and Environmental Microbiology, vol. 79, no. 20, pp. 6325-6330, 2013.

[13] M. J. Somerman, S. Y. Archer, G. R. Imm, and R. A. Foster, "A comparative study of human periodontal ligament cells and gingival fibroblasts in vitro," Journal of Dental Research, vol. 67 , no. 1, pp. 66-70, 1988.

[14] C. M. Overall and J. Sodek, "Initial characterization of a neutral metalloproteinase, active on native 3/4-collagen fragments, synthesized by ROS 17/2.8 osteoblastic cells, periodontal fibroblasts, and identified in gingival crevicular fluid," Journal of Dental Research, vol. 66, no. 7, pp. 1271-1282, 1987.

[15] X. Han and S. Amar, "Identification of genes differentially expressed in cultured human periodontal ligament fibroblasts vs. human gingival fibroblasts by DNA microarray analysis," Journal of Dental Research, vol. 81, no. 6, pp. 399405, 2002. 
[16] S. Takashiba, K. Naruishi, and Y. Murayama, "Perspective of cytokine regulation for periodontal treatment: fibroblast biology," Journal of Periodontology, vol. 74, no. 1, pp. 103-110, 2003.

[17] R. Gothi, N. Sangwan, A. Kaushik, and N. Sikka, "Periodontal ligament stem cells-the regeneration front," Dentistry, vol. 5, no. 1, 2015.

[18] T. Mosmann, "Rapid colorimetric assay for cellular growth and survival: application to proliferation and cytotoxicity assays," Journal of Immunological Methods, vol. 65, no. 1-2, pp. 55-63, 1983.

[19] Y. Rai, R. Pathak, N. Kumari et al., "Mitochondrial biogenesis and metabolic hyperactivation limits the application of MTT assay in the estimation of radiation induced growth inhibition," Scientific Reports, vol. 8, no. 1, p. 1531, 2018.

[20] H. Akagi, Mercury Analysis Manual, Tokyo, Japan, Ministry of the Environment, 2004.

[21] N. P. Singh and R. E. Stephens, "Microgel electrophoresis: sensitivity, mechanisms, and DNA electrostretching," Mutation Research/DNA Repair, vol. 383, no. 2, pp. 167-175, 1997.

[22] S. M. San Miguel, L. A. Opperman, E. P. Allen, J. E. Zielinski, and K. K. H. Svoboda, "Antioxidant combinations protect oral fibroblasts against metal-induced toxicity," Archives of Oral Biology, vol. 58, no. 3, pp. 299-310, 2013.

[23] P. S. Green and C. Leeuwenburgh, "Mitochondrial dysfunction is an early indicator of doxorubicin-induced apoptosis," Biochimica et Biophysica Acta (BBA) - Molecular Basis of Disease, vol. 1588, no. 1, pp. 94-101, 2002.

[24] S. M. de la Monte and J. R. Wands, "Alzheimer-associated neuronal thread protein-induced apoptosis and impaired mitochondrial function in human central nervous systemderived neuronal cells," Journal of Neuropathology \& Experimental Neurology, vol. 60, no. 2, pp. 195-207, 2001.

[25] J. C. Stockert, A. Blázquez-Castro, M. Cañete, R. W. Horobin, and A. Villanueva, "MTT assay for cell viability: intracellular localization of the formazan product is in lipid droplets," Acta Histochemica, vol. 114, no. 8, pp. 785-796, 2012.

[26] M. V. Berridge, A. S. Tan, K. D. McCoy, and R. Wang, “The biochemical and cellular basis of cell proliferation assays that use tetrazolium salts," Biochemica, vol. 4, pp. 14-19, 1996.

[27] M. V. Berridge, P. M. Herst, and A. S. Tan, "Tetrazolium dyes as tools in cell biology: new insights into their cellular reduction," Biotechnology Annual Review, vol. 11, pp. 127-152, 2005.

[28] T. Bernas and J. W. Dobrucki, "Mitochondrial and nonmitochondrial reduction of MTT: interaction of MTT with TMRE, JC-1, and NAO mitochondrial fluorescent probes," Cytometry, vol. 47, no. 4, pp. 236-242, 2002.

[29] Z. Castilhos, S. Rodrigues-Filho, R. Cesar et al., "Human exposure and risk assessment associated with mercury contamination in artisanal gold mining areas in the Brazilian Amazon," Environmental Science and Pollution Research International, vol. 22, no. 15, pp. 11255-11264, 2015.

[30] E. J. Martinez-Finley and M. Aschner, "Recent advances in mercury research," Current Environmental Health Reports, vol. 1, no. 2, pp. 163-171, 2014.

[31] M. Farina, J. B. Rocha, and M. Aschner, "Mechanisms of methylmercury-induced neurotoxicity: evidence from experimental studies," Life Sciences, vol. 89, no. 15-16, pp. 555-563, 2011.

[32] S. B. Nimse and D. Pal, "Free radicals, natural antioxidants, and their reaction mechanisms," RSC Advances, vol. 5, no. 35, pp. 27986-28006, 2015.
[33] M. E. Crespo-López, G. L. Macêdo, S. I. D. Pereira et al., "Mercury and human genotoxicity: critical considerations and possible molecular mechanisms," Pharmacological Research, vol. 60, no. 4, pp. 212-220, 2009.

[34] A. Martín-Cameán, Á. Jos, P. Mellado-García, A. IglesiasLinares, E. Solano, and A. M. Cameán, "In vitro and in vivo evidence of the cytotoxic and genotoxic effects of metal ions released by orthodontic appliances: A review," Environmental Toxicology and Pharmacology, vol. 40, no. 1, pp. 86-113, 2015.

[35] G. Visalli, B. Baluce, S. La Maestra et al., "Genotoxic damage in the oral mucosa cells of subjects carrying restorative dental fillings," Archives of Toxicology, vol. 87, no. 1, pp. 179-187, 2013.

[36] R. G. Contreras, H. Sakagami, H. Nakajima, and J. Shimada, "Type of cell death induced by various metal cations in cultured human gingival fibroblasts," In Vivo, vol. 24, no. 4, pp. 513-517, 2010.

[37] A. Barzilai and K. Yamamoto, "DNA damage responses to oxidative stress," DNA Repair, vol. 3, no. 8-9, pp. 1109-1115, 2004.

[38] D. C. Van Gent, J. H. Hoeijmakers, and R. Kanaar, "Chromosomal stability and the DNA double-stranded break connection," Nature Reviews Genetics, vol. 2, no. 3, pp. 196-206, 2001.

[39] T. Eliades, H. Pratsinis, D. Kletsas, G. Eliades, and M. Makou, "Characterization and cytotoxicity of ions released from stainless steel and nickel-titanium orthodontic alloys," American Journal of Orthodontics and Dentofacial Orthopedics, vol. 125, no. 1, pp. 24-29, 2004.

[40] F. Faccioni, P. Franceschetti, M. Cerpelloni, and M. E. Fracasso, "In vivo study on metal release from fixed orthodontic appliances and DNA damage in oral mucosa cells," American Journal of Orthodontics and Dentofacial Orthopedics, vol. 124, no. 6, pp. 687-693, 2003. 


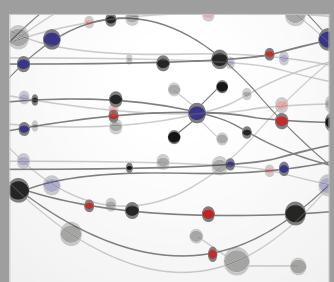

The Scientific World Journal
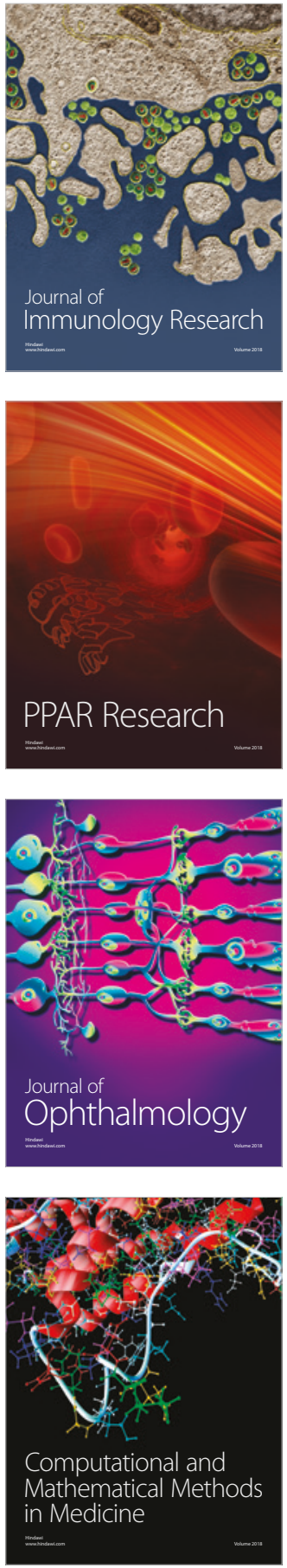

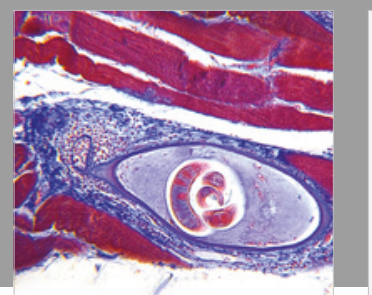

Gastroenterology Research and Practice

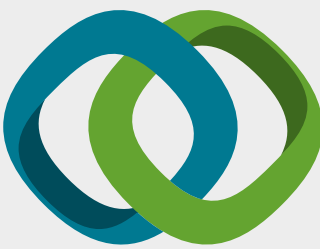

\section{Hindawi}

Submit your manuscripts at

www.hindawi.com
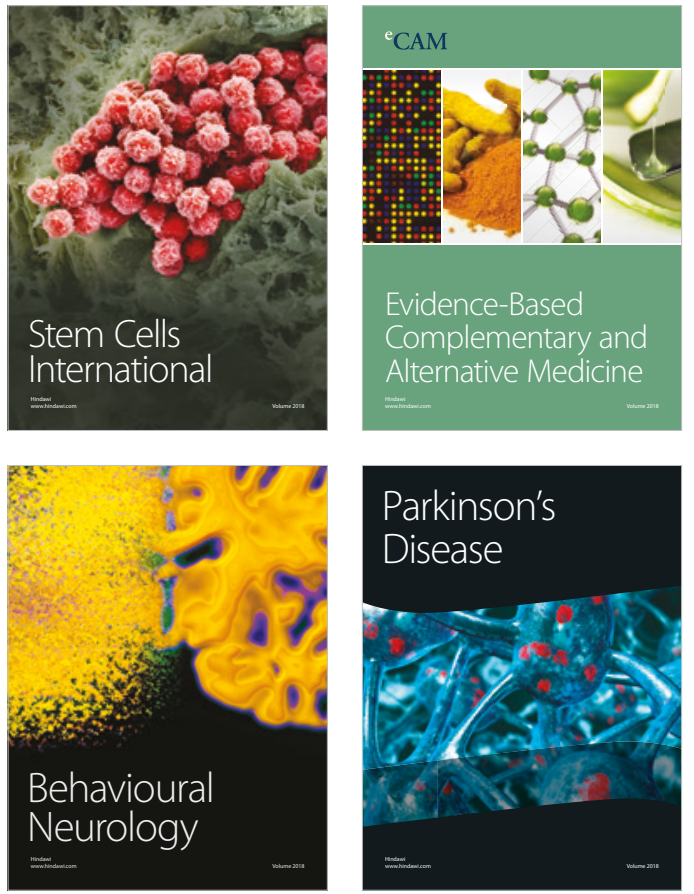

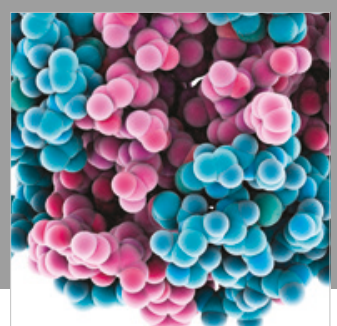

ournal of

Diabetes Research

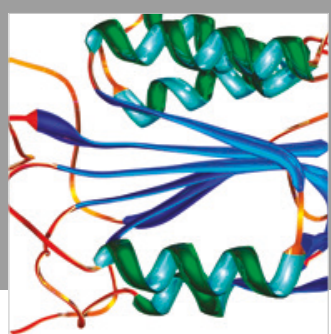

Disease Markers
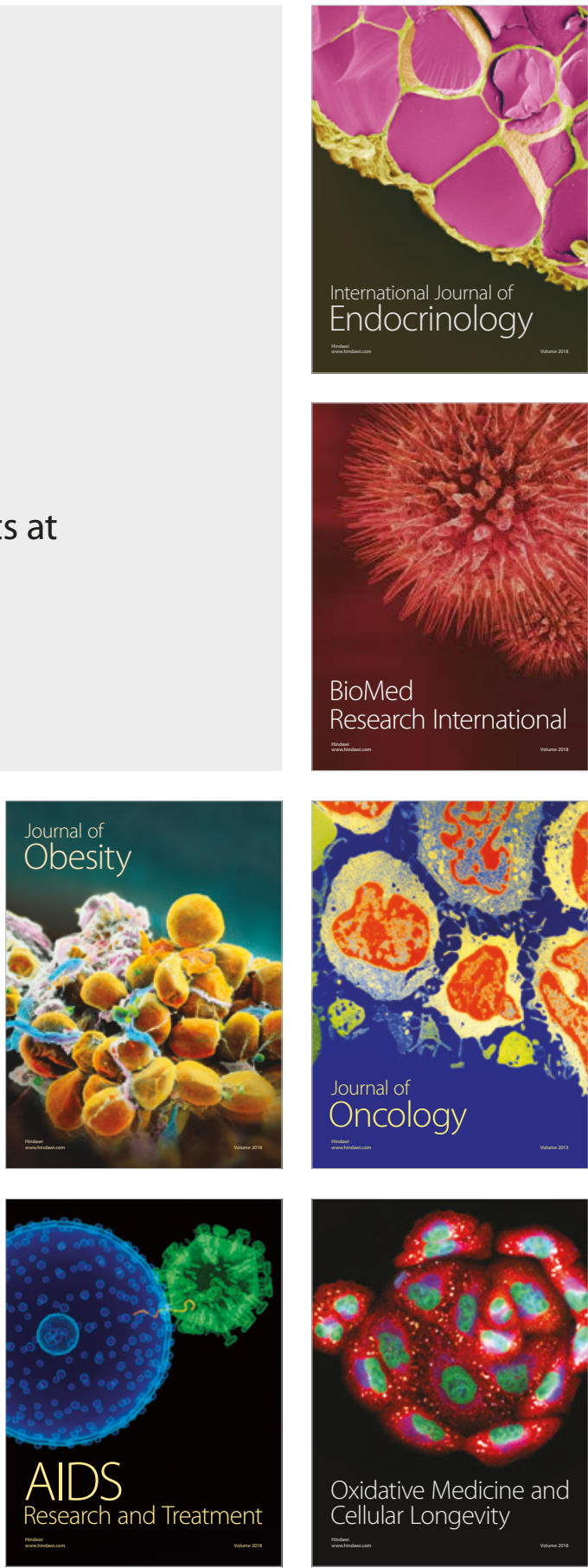